\title{
Sheep and Goat Production in Portugal: A Dynamic View
}

\author{
Manuel Luís Tibério, Francisco Diniz² \\ ${ }^{1}$ Departamento de Economia, Sociologia e Gestão, Centro de Estudos Transdisciplinares para o, \\ Vila Real, Portugal \\ ${ }^{2}$ Desenvolvimento, Universidade de Trás-os-Montes e Alto Douro, Vila Real, Portugal \\ Email: $\underline{\text { mtiberio@utad.pt, fdiniz@utad.pt }}$
}

Received 17 February 2014; revised 17 March 2014; accepted 30 March 2014

Copyright (C) 2014 by authors and Scientific Research Publishing Inc.

This work is licensed under the Creative Commons Attribution International License (CC BY). http://creativecommons.org/licenses/by/4.0/

(c) (7) Open Access

\begin{abstract}
Sheep production is probably one of the oldest productions in the world. In early years this animal was considered as a domestic and productive one, since it provided families with milk, meat and wool. Besides providing all these products, the animals were not difficult to grow. They fed on many different floras that others would leave so their owners started to walk great distances with them to get the best grazing spots in winter and in summer. They called this transhumance. But in nowadays, animal feed became easier to get to. It was no longer necessary to move all the animals to pastures hundreds of kilometers away, and producers started going for shorter distances. Production also got more intensive, although sheep production was always considered to be more extensive rather than intensive. With this revision we intend to go over all the statistics concerning this production in Portugal and compare it in different years, to establish a correlation between them. Although sheep production is made entirely with autochthonous breeds and these are milk and meat production oriented, the meat production has a higher relevance in the sector. So it was necessary to make a more thorough approach to this production. There is also an interest in new and emergent ways of production which we discuss at the end of this revision, along with a small global analysis.
\end{abstract}

\section{Keywords}

Sheep and Goat Food Chain, Rural Development, Quality Products' Certification

\section{Introduction}

The main purpose of this research is to give an overview of the food chain of sheep and goat in Portugal bearing in mind that all the production chain is from the producer to the market. 
We considered some studies made between 1999 and 2009 and an analysis from 2012. We also took into account world statistics and related them to the Portuguese ones. Making a comparison between the two, we were able to make some conclusions about the situation of sheep production in Portugal. The content from several other studies was summarized into this revision with the purpose of gathering some scattered information about sheep production. It is a descriptive research that uses quantitative information, provided by the National Statistics Institute (INE), on the development of farms and sheep and goat populations at national and regional levels as well as the characteristic elements of production and domestic consumption of meat from these two species. The study also uses the qualitative information gathered from various secondary sources.

\section{Sheep and Goat Production in Portugal}

\subsection{Farmers and Sheep Herd}

In Portugal about 52,000 sheep farms and a total number of 2.2 million animals have been identified. The sheep farms with dairy aptitude are approximately 8500 and have a population of 424,000 animals (Table 1).

Sheep production in Portugal is mainly oriented to meat production. The dairy herd (circa 425,000 animals) represents about $20 \%$ of the national sheep number and is spread over 8500 farms (about $17 \%$ of the farms). Dairy sheep farms are more relevant in the regions of Beira Interior (BI) and Beira Litoral (BL) (Figure 1).

Sheep production is an activity with a significant concentration at regional level. In fact, of the 2.2 million sheep existing, nearly $50 \%$ are in the Alentejo region (Figure 2), which concentrates $16 \%$ of farms (Figure 3 ).

Regarding the herd, sheep farms have a more balanced regional distribution, although the ones located in Entre Douro e Minho (EDM 24\%); Beira Litoral (BL 22\%); Alentejo (ALE 16\%) and Ribatejo and Oeste (RO 14\%) do stand out (Figure 3).

Sheep milk production is characteristic of the Beira Interior region (BI), which concentrates $53 \%$ of the national sheep flock with milk aptitude (Figure 4) and 32\% of farms (Figure 5). The second largest dairy herd is located in Alentejo (13\%) and, despite representing only 5\% of the regional sheep flock, it is the sheep meat production area par excellence.

As mentioned above, the production of sheep milk is also of some importance in Beira Litoral, concentrating $35 \%$ of farms and $12 \%$ of the herd, and Ribatejo Oeste, with $14 \%$ of the farms and $9 \%$ of the herd.

In the period between 1999 and 2009, there was a widespread decrease of sheep production in Portugal, reflecting itself on an average reduction of $27 \%$ of the number of farms and $24 \%$ of the herd. This negative change, which affected all regions, was more pronounced in the Algarve (ALG), in Ribatejo Oeste (RO) and in Madeira (Figure 6).

Table 1. Farmers and number of sheep in production.

\begin{tabular}{|c|c|c|c|c|c|c|c|c|}
\hline \multicolumn{9}{|c|}{ Sheep Population per region } \\
\hline \multirow{2}{*}{ Regions } & \multicolumn{4}{|c|}{ Sheep (Total) } & \multicolumn{4}{|c|}{ Dairy Sheep } \\
\hline & Farmers $\left(n^{0}\right)$ & $(\%)$ & $\mathrm{N}^{\circ}$ & $(\%)$ & Farmers $\left(n^{\circ}\right)$ & $(\%)$ & $\mathrm{N}^{\circ}$ & (\%) \\
\hline Portugal & 51,787 & 100 & $2,219,639$ & 100 & 8,551 & 100 & 424,448 & 100 \\
\hline EDM & 12,721 & 25 & 129,148 & 6 & 2 & 0 & 350 & 0 \\
\hline $\mathrm{TM}$ & 4436 & 9 & 269,726 & 12 & 889 & 10 & 51,609 & 12 \\
\hline $\mathrm{BL}$ & 11,464 & 22 & 143,866 & 6 & 2987 & 35 & 50,301 & 12 \\
\hline BI & 5550 & 11 & 359,200 & 16 & 2695 & 32 & 224,305 & 53 \\
\hline RO & 7082 & 14 & 173,803 & 8 & 1227 & 14 & 39,964 & 9 \\
\hline ALE & 8133 & 16 & $1,090,421$ & 49 & 248 & 3 & 54,239 & 13 \\
\hline ALG & 811 & 2 & 45,009 & 2 & 97 & 1 & 2171 & 1 \\
\hline Açores & 638 & 1 & 3850 & 0 & 148 & 2 & 436 & 0 \\
\hline Madeira & 952 & 2 & 4616 & 0 & 258 & 3 & 1,073 & 0 \\
\hline
\end{tabular}

Source: INE, 2011. 


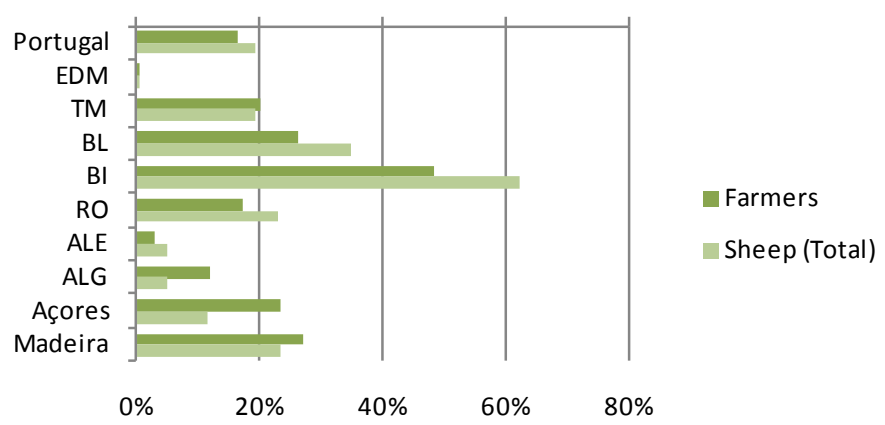

Figure 1. Representativeness of the dairy sheep population.

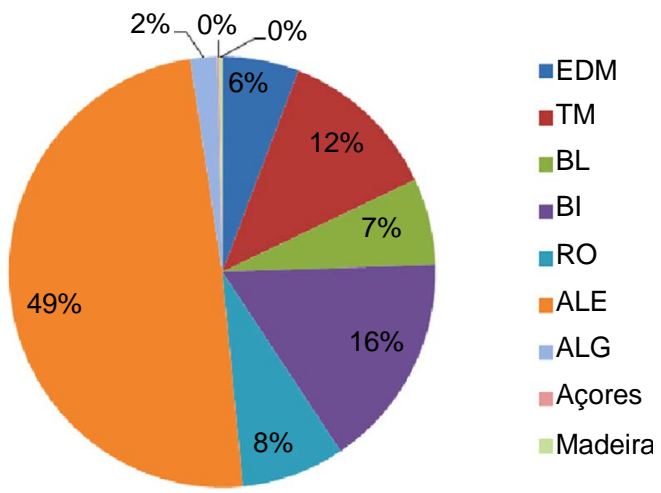

Figure 2. Total sheep per region.

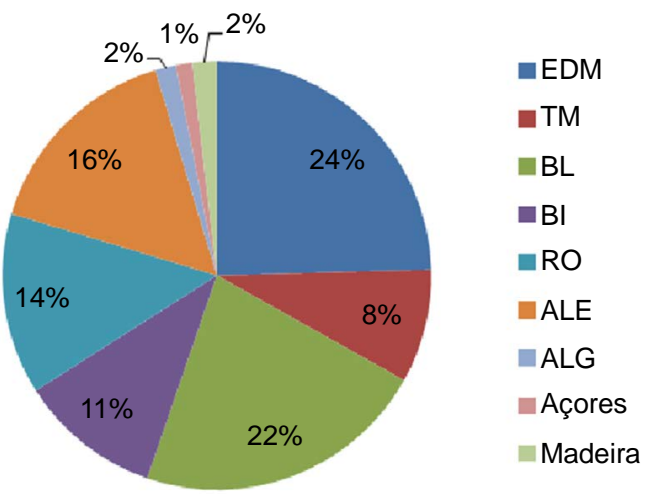

Figure 3. Sheep farms per region.

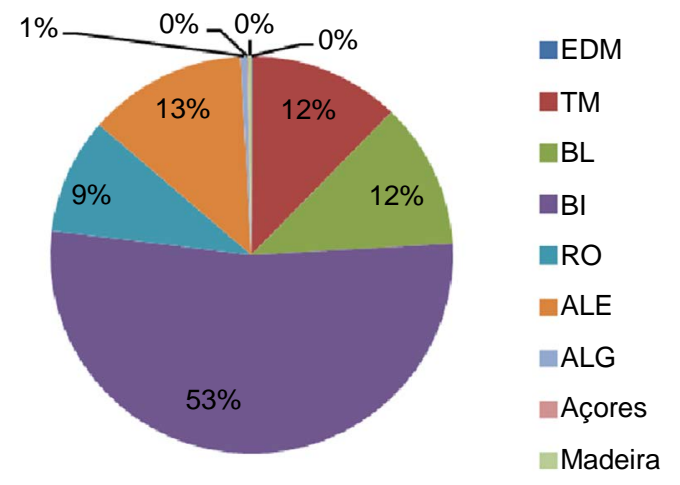

Figure 4. Total dairy sheep per region. 


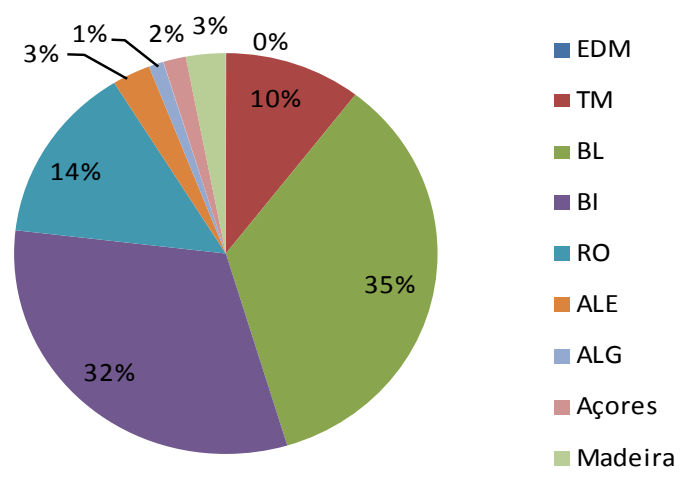

Figure 5. Dairy sheep farms per region.

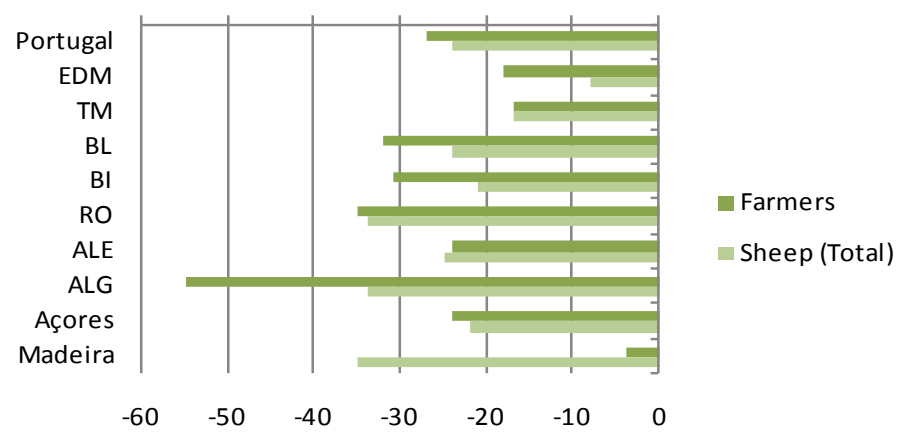

Figure 6. Sheep population (Var. 1999-2009, \%).

\subsection{Sheep Production Structure}

The average size of sheep farms in Portugal, whether dairy or non-dairy, is less than 50 animals per farm (Figure 7). In general, milk farms tend to have an average size greater than the meat farms, especially in the regions of Entre Douro e Minho (North) and Alentejo (South). Although the number of sheep producers is decreasing, the number of animals in each farm is increasing, meaning that small scale production is disappearing and is being replaced by large scale production. Anyway, the average size of sheep farms recorded a very slight increase between 1999 and 2009, from 41 to 43 animals per farm [1].

As mentioned before, Portugal has a big concentration of sheep production in Alentejo, where the herd size is bigger than in any other region. In fact, this is the only region where farms have an average of more than one hundred animals per farm. In regions like Trás-os-Montes and Beira Interior we can only find medium-sized herds.

The distribution of livestock by farm size classes has not changed significantly, although there was a decrease in the number of farms with less than 10 heads and an increase of holdings in larger classes, especially in classes with 10 to 19 and 20 to 49 animals (Figure 8). When we look at Figure 8, we can see that the number of farms having small-sized herds has decreased, replaced by medium-sized ones, having between 10 and 49 animals. The medium high and larger farms have been maintained and one can see that farms with between 200 and 499 animals have increased [2].

The very small farms (1 - 9 animals) represent $50 \%$ of the total number farms and only $5 \%$ of the herd. Large farms (with more than 500 animals per farm) represent only $2 \%$ of the universe but hold about $30 \%$ of livestock (Figure 9).

Figure 10 highlights the concentration of very small sheep farms in the coastal region in the north of the country and the medium and large farms in the interior, especially in the southern interior (the Alentejo region). One can also see how dairy sheep production is concentrated on the Centre whereas expertise on meat production lies in Alentejo.

\subsection{Farmers and Goat Herds}

Regarding goat production in Portugal about 32,000 farms and 420,000 animals have been identified (Table 2), 


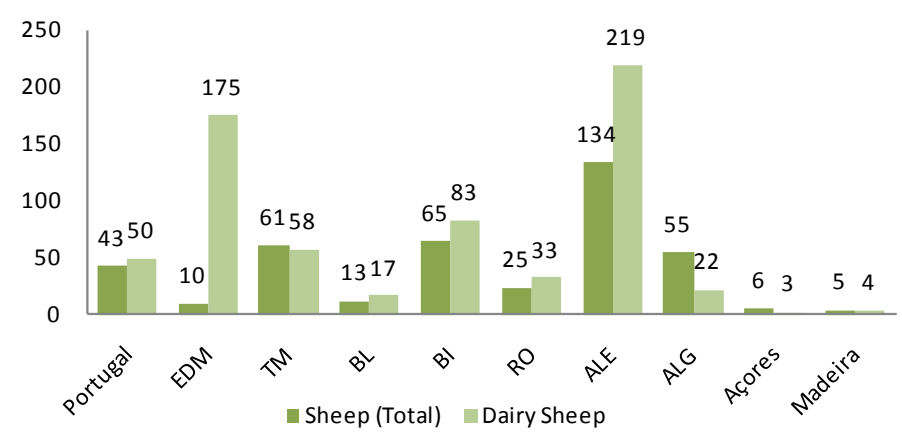

Figure 7. Average heard size $\left(\mathrm{n}^{\mathrm{a}}\right)$.

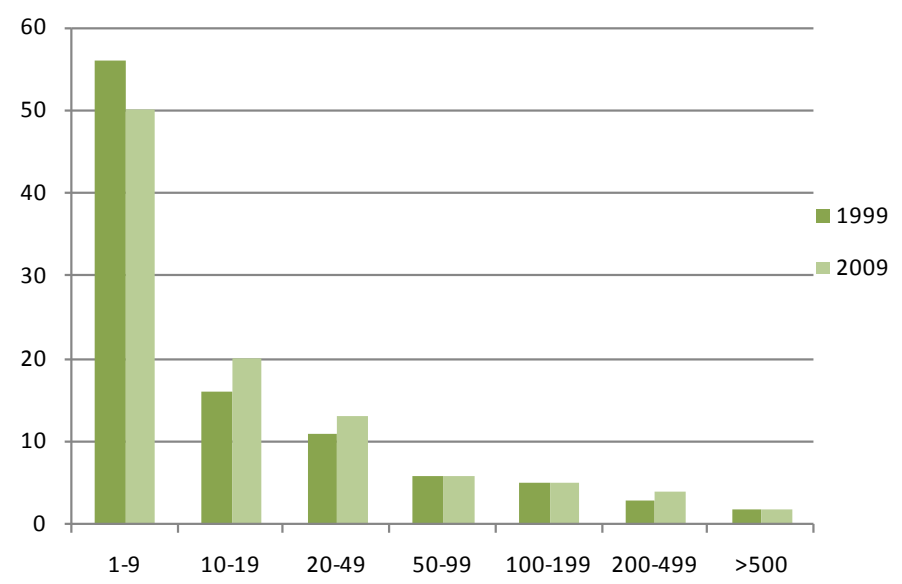

Figure 8. Farmers by size classes (\%).

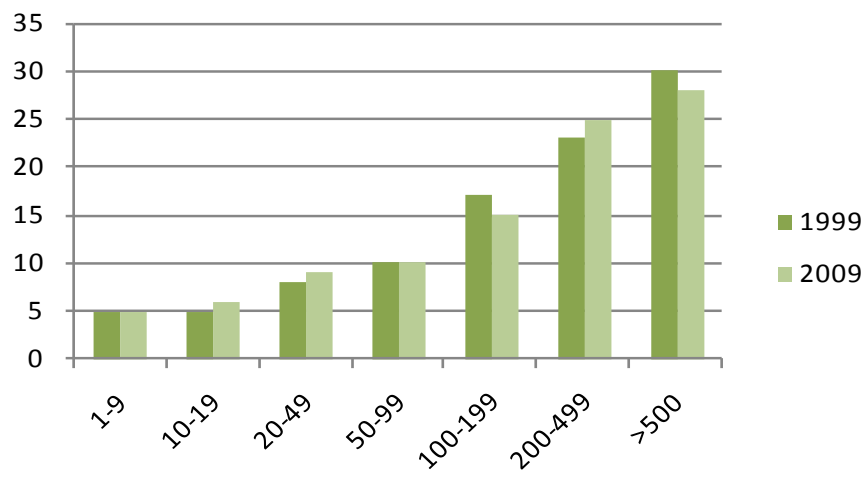

Figure 9. Sheep population by size classes (no).

which translates to an average of 13 animals per farm. Goat farms and the goat livestock correspond to $60 \%$ and $20 \%$ of the sheep farms and the sheep livestock, respectively.

In Portugal goat production is also more meat than dairy oriented. However, goat farms reveal a greater milk tendency than sheep farms. The dairy herd (about 150,000 animals) represents about $35 \%$ of the goat population and is distributed over approximately 12,000 farms, which represents approximately $36 \%$ of the total number of goat farms. As it happens with sheep production, it is also in Beira Interior that dairy goat farms are more relevant (Figure 11).

Goat production records a more balanced regional distribution sheep production, both in terms of livestock (Figure 12) and at farm level (Figure 13). The 420,000 heads are distributed regionally as shown in Figure 13; the Alentejo stands out (24\% of livestock) compared to the regions of Beira Interior (16\%), and Beira Litoral (15\%). 

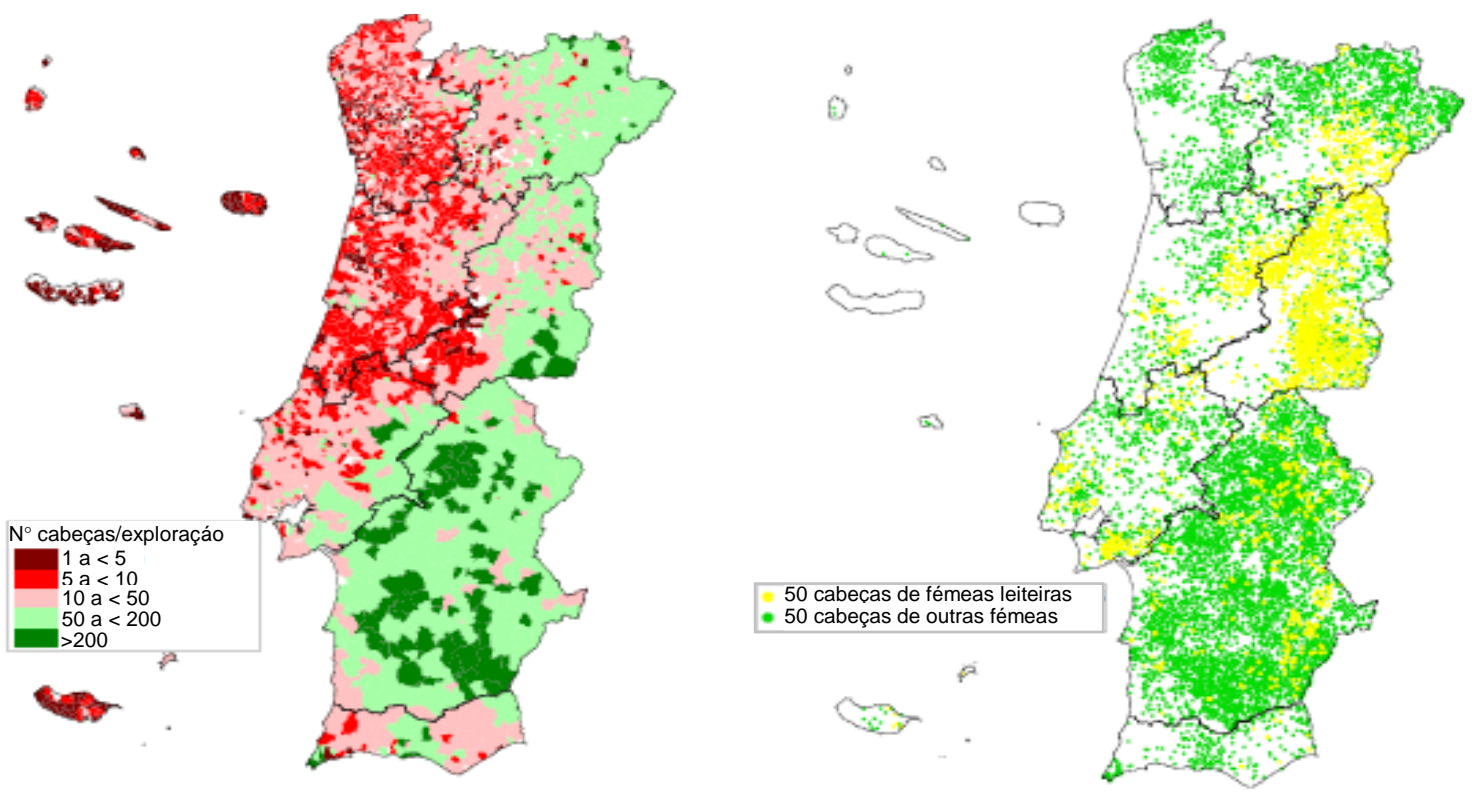

Figure 10. Average herd size and sheep distribution. Source: INE, 2011.

Table 2. Farmers and number of goat in production.

\begin{tabular}{|c|c|c|c|c|c|c|c|c|}
\hline \multicolumn{9}{|c|}{ Goat Population, per region } \\
\hline \multirow{2}{*}{ Regions } & \multicolumn{4}{|c|}{ Goat (Total) } & \multicolumn{4}{|c|}{ Dairy goat } \\
\hline & Farmers $\left(\mathrm{n}^{0}\right)$ & $(\%)$ & $\mathrm{N}^{\circ}$ & $(\%)$ & Farmers $\left(\mathrm{n}^{\circ}\right)$ & $(\%)$ & $\mathrm{N}^{\circ}$ & $(\%)$ \\
\hline Portugal & 32,514 & 100 & 420,711 & 100 & 11,861 & 100 & 149,295 & 100 \\
\hline EDM & 4560 & 14 & 54,819 & 13 & 15 & 0 & 2029 & 1 \\
\hline $\mathrm{TM}$ & 1945 & 6 & 57,006 & 14 & 539 & 5 & 14,881 & 10 \\
\hline BL & 9715 & 30 & 64,244 & 15 & 3044 & 26 & 16,560 & 11 \\
\hline BI & 6209 & 19 & 66,172 & 16 & 4424 & 37 & 40,993 & 27 \\
\hline RO & 2927 & 9 & 48,656 & 12 & 1158 & 10 & 27,495 & 18 \\
\hline ALE & 2418 & 7 & 99,155 & 24 & 570 & 5 & 35,510 & 24 \\
\hline ALG & 738 & 2 & 15,575 & 4 & 206 & 2 & 6268 & 4 \\
\hline Açores & 1711 & 5 & 8018 & 2 & 980 & 8 & 3575 & 2 \\
\hline Madeira & 2291 & 7 & 7066 & 2 & 925 & 8 & 1984 & 1 \\
\hline
\end{tabular}

Source: INE, 2011.

The regional distribution of farms reveals greater concentration and is not entirely consistent with the livestock distribution. Beira Litoral holds $30 \%$ of the farms and only $15 \%$ of livestock, while in the Alentejo region (the largest producer) there are only $8 \%$ of farms (Figure 13).

On the other hand, according to Figure 14, goat milk production (70\%) is concentrated in three regions: Beira Interior (28\%), Alentejo (24\%) and Ribatejo Oeste (19\%).

Beira Interior (37\%) and Beira Litoral (26\%) together account for over 60\% of dairy goat farms (Figure 15). This territory represents only $11 \%$ of the dairy goat animals. The Alentejo region holds only $5 \%$ of the farms and $24 \%$ of the dairy goat animals.

Like sheep production, goat production is also facing a deep decrease. At the county level, in the period under review (1999-2009), 40\% of farms abandoned the activity, and reduced the livestock by 22\%. This negative 


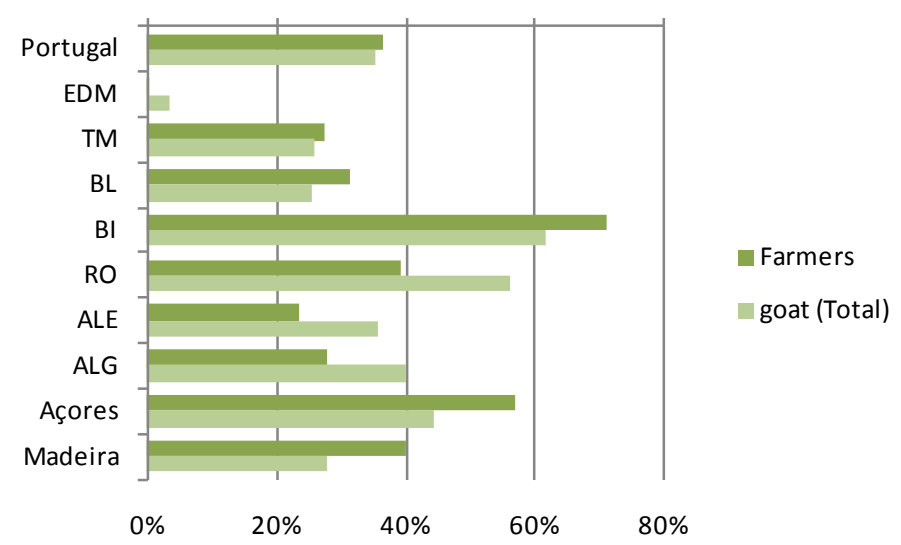

Figure 11. Representativeness of the dairy goat population.

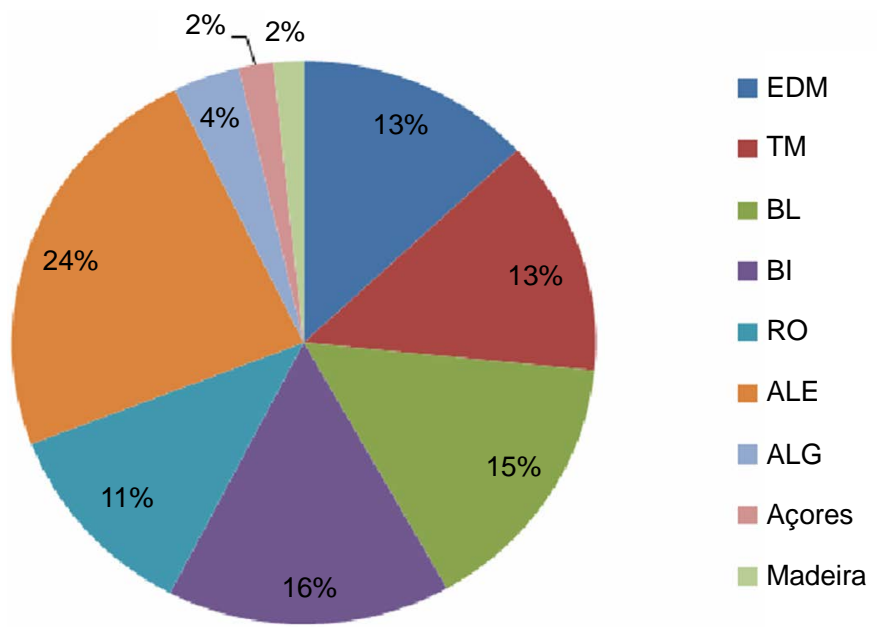

Figure 12. Total of goats per region.

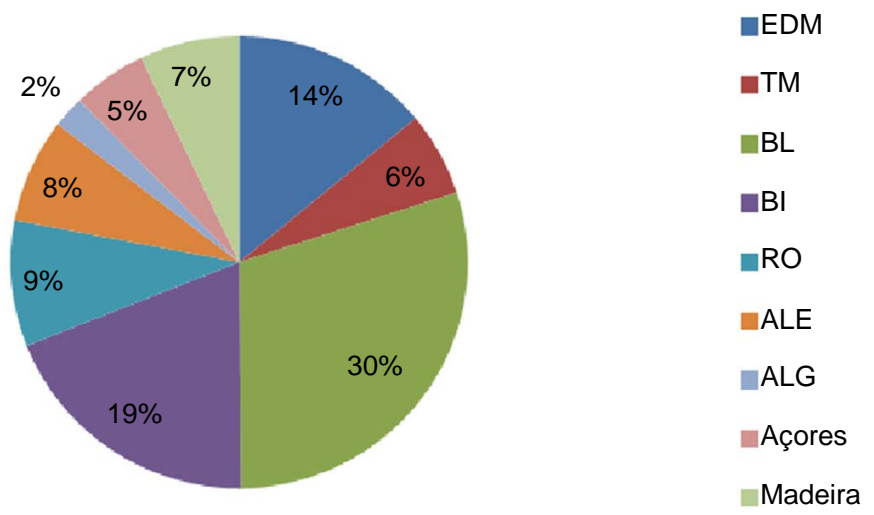

Figure 13. Goat farms per region.

growth was recorded in all regions but it was especially severe in the regions of Beira Interior and Algarve. In the Ribatejo Oeste, the goat population increased slightly, though (Figure 16).

\subsection{Goat Production Structure}

As shown in Figure 17 and mentioned earlier, goat farms in Portugal are very small. The average size of goat herds (13 animals) is considerably lower than that of sheep, and increased only 3 heads in 1999 [1]. Also, in this 


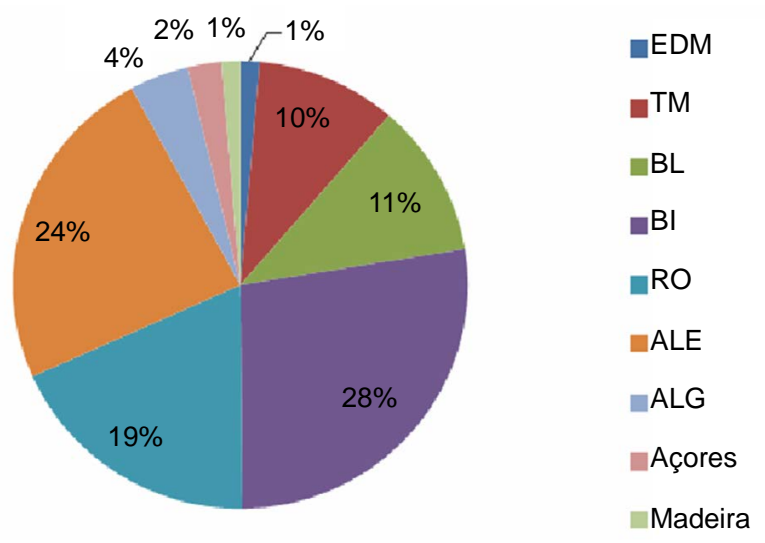

Figure 14. Total of dairy goats per region.

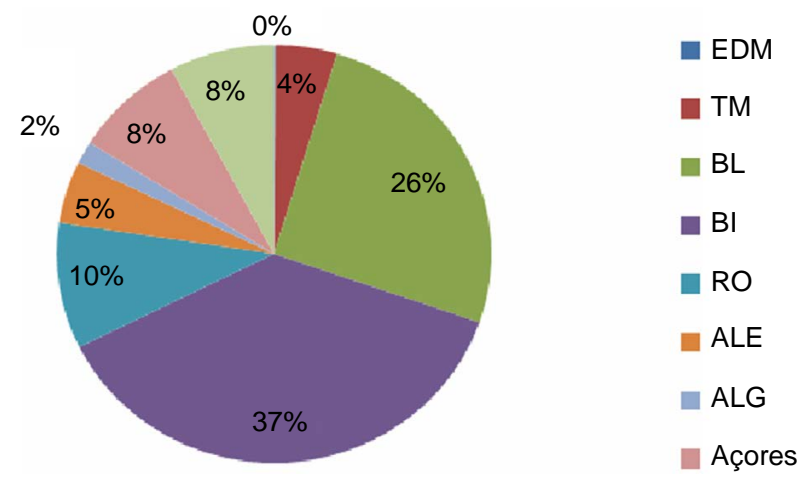

Figure 15. Dairy goat farms per region.

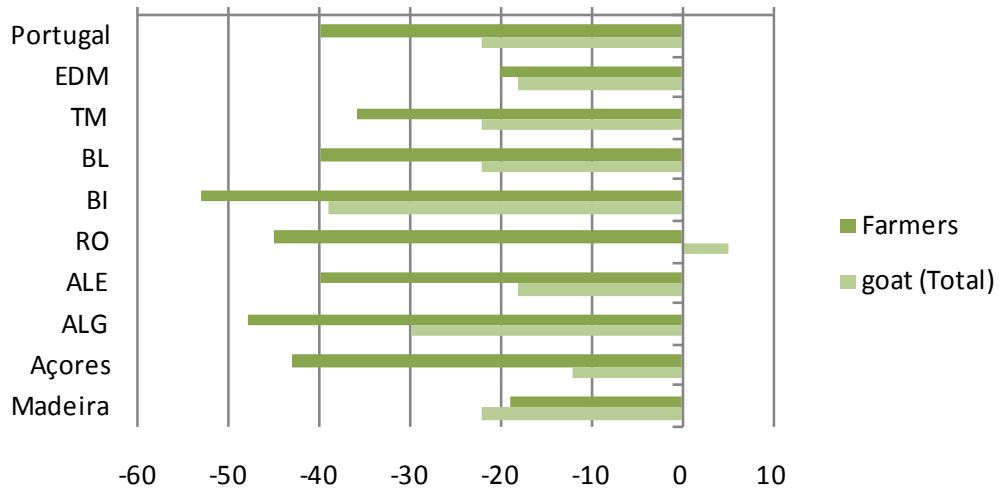

Figure 16. Goat population (Var. 1999-2009, \%).

activity, dairy farms tend to be larger than meat oriented ones. This is even more striking in the Alentejo region, where the average farm size is larger (about 60 animals per farm). The average size of dairy goat farms in the region of Entre Douro e Minho is not representative of the national situation, since we are referring to a very small number of farms (15).

As regards the goat production structure, Figure 17 shows that about $80 \%$ of farms have less than 9 animals [1], being very small, indeed.

These very small farms (which are vast majority of farms) represent only about $20 \%$ of the total heard. A very small number of large farms (2\%) in the 100 - 499 animals' class represent $35 \%$ of the herd. This type of farms has increased its representativeness, though (Figure 18, Figure 19).

Figure 18 shows that smaller farms are located in the northern coast region, as indeed is the case with sheep 


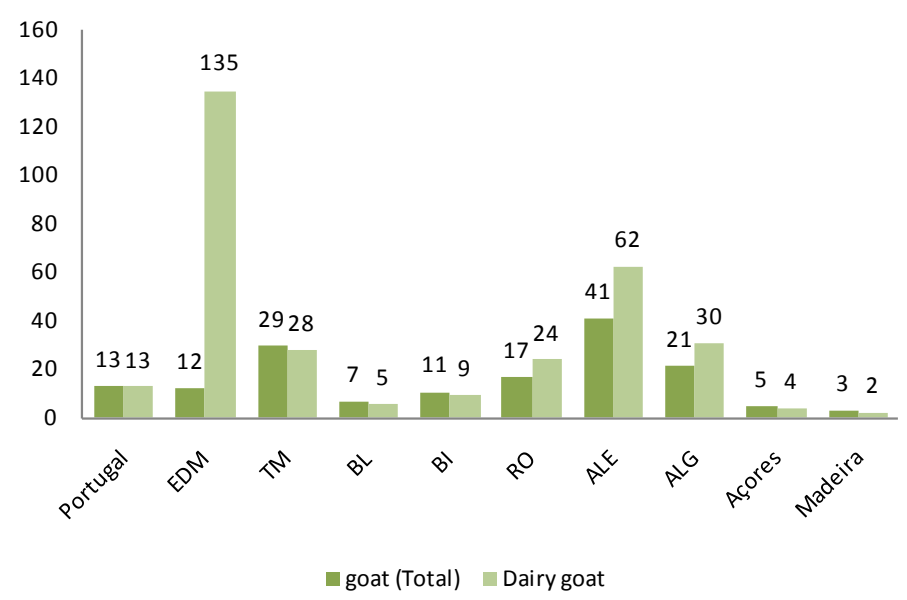

\section{Figure 17. Average heard size.}

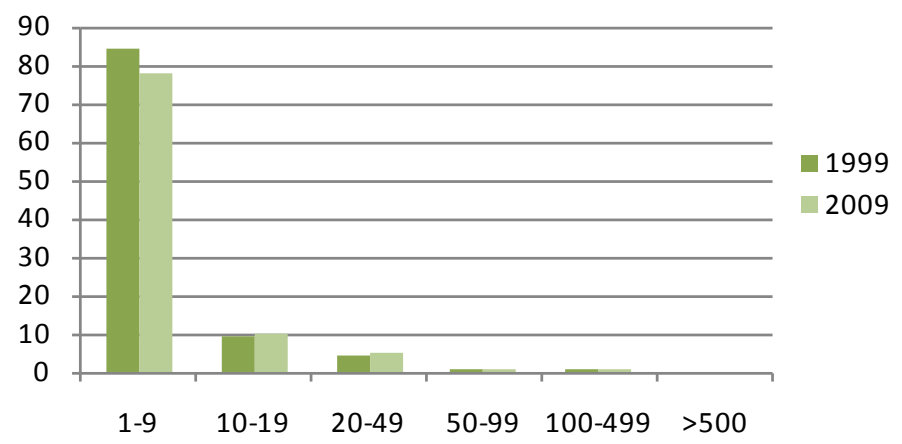

Figure 18. Farmers by size classes (no).

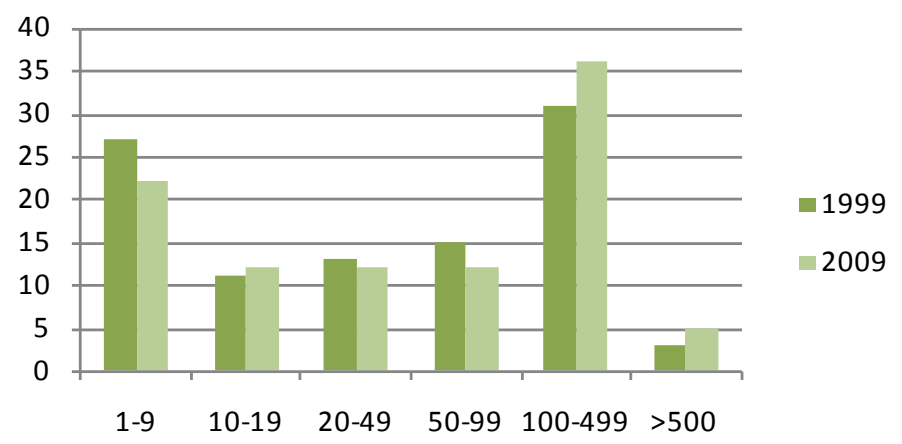

Figure 19. Sheep population by size classes (\%).

production. It can also be argued that the dairy goat production is an activity dispersed throughout the country, revealing lower concentration than sheep production.

\subsection{Autochthonous Breeds in the Frame of Sheep and Goat National Production}

Portugal has important reserves of genetic resources of which 45 indigenous breeds have been officially recognized: 15 bovine, 15 sheep, 5 goats, 3 pigs, 4 horses and 3 chickens [3]. As said before, Portugal has fifteen autochthonous sheep breeds with specific characteristics (Table 3). Some are oriented to meat production, others to milk and some have double orientation, meaning they can combine a high prolificacy with a good milk aptitude. There are also some breeds that have triple aptitude, although currently there is almost no interest in wool production.

The approximately 112,000 indigenous females enrolled in the Zootechnical Register (Studbook) represent 
$5 \%$ of the total national sheep and $27 \%$ of the milk goat livestock.

Terra Quente Churra breed (20\%), predominantly in the northeastern interior of the country, and the Serra da Estrela breed (16\%), in the Centre Interior are the most representative Portuguese autochthonous breeds (Figure 20, Figure 21).

In northern Portugal, there are six breeds, the main one being Churra da Terra Quente. This is also the main in the country, since about 22 thousand animals of this breed are enrolled in the genealogical book. Churra da Terra Quente, along with Churra Badana, are used for their reproductive capacity, namely the production of lambs

Table 3. Sheep local breed.

\begin{tabular}{|c|c|}
\hline Breed & Female $\left(\mathrm{N}^{\circ}\right)$ \\
\hline Bordaleira de Entre-Douro e Minho & 6080 \\
\hline Campaniça & 6.654 \\
\hline Churra Algarvia & 2.786 \\
\hline Churra Badana & 2.959 \\
\hline Churra da Terra Quente & 22.247 \\
\hline Churra do Campo & 128 \\
\hline Churra Galega Bragançana & 9.700 \\
\hline Churra Galega Mirandesa & 6.895 \\
\hline Merina Beira Baixa & 7.167 \\
\hline Merina Branca & 8.500 \\
\hline Merina Precoce & 698 \\
\hline Merina Preta & 10.000 \\
\hline Mondegueira & 3.500 \\
\hline Saloia & 6.919 \\
\hline Serra da Estrela & 18.521 \\
\hline Total & 112.754 \\
\hline
\end{tabular}

Source: DJV (2007).
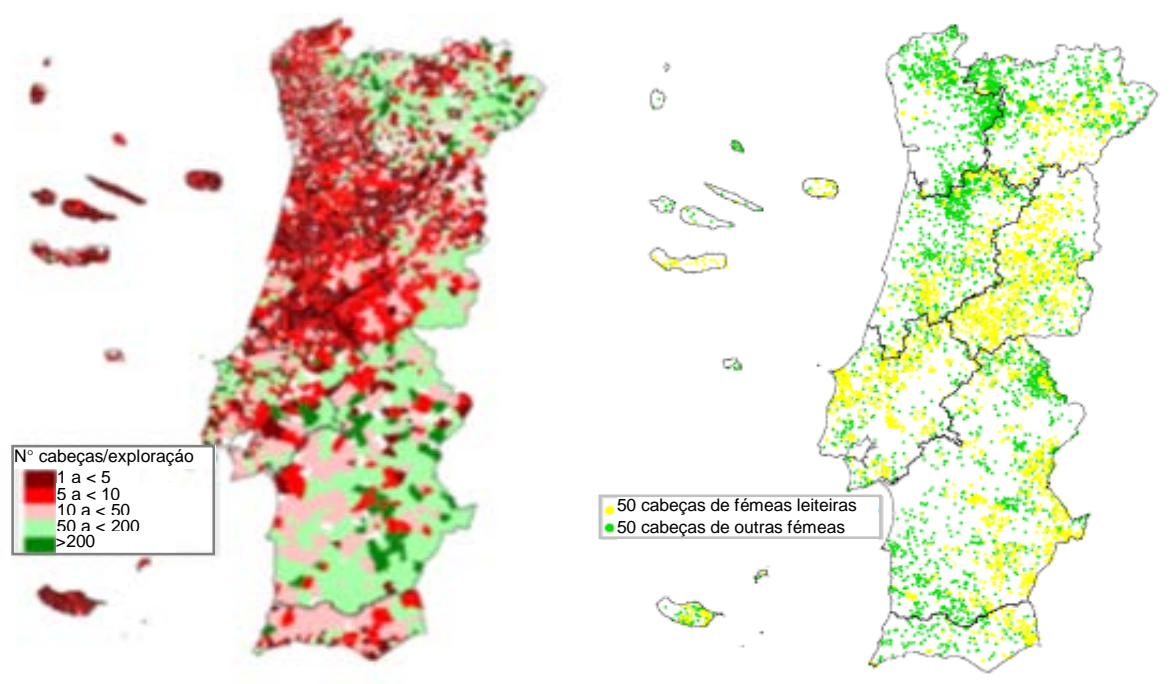

Figure 20. Average herd size and goat distribution, Source: INE, 2011. 
for their meat; however, their milk aptitude is also good, whereby one can speak of a double aptitude. Churra Galega Bragançana, Bordaleira de Entre Douro e Minho, Churra do Minho and Churra Galega Mirandesa are meat production oriented breeds that can also be found in the north.

Figure 22 illustrates the distribution of native breeds of sheep in northern Portugal.

In the central region of the country, the main breed is Serra da Estrela. Known for the cheese that adopts the same name but also for its lambs, this region has about 18,500 animals enrolled in the genealogical book. Besides Serra da Estrela, other breeds like Merino Preto and Merino da Beira Baixa also have double aptitude. Although it isn't the breed with most animals enrolled, the Merino Branco breed has the largest amplitude in the

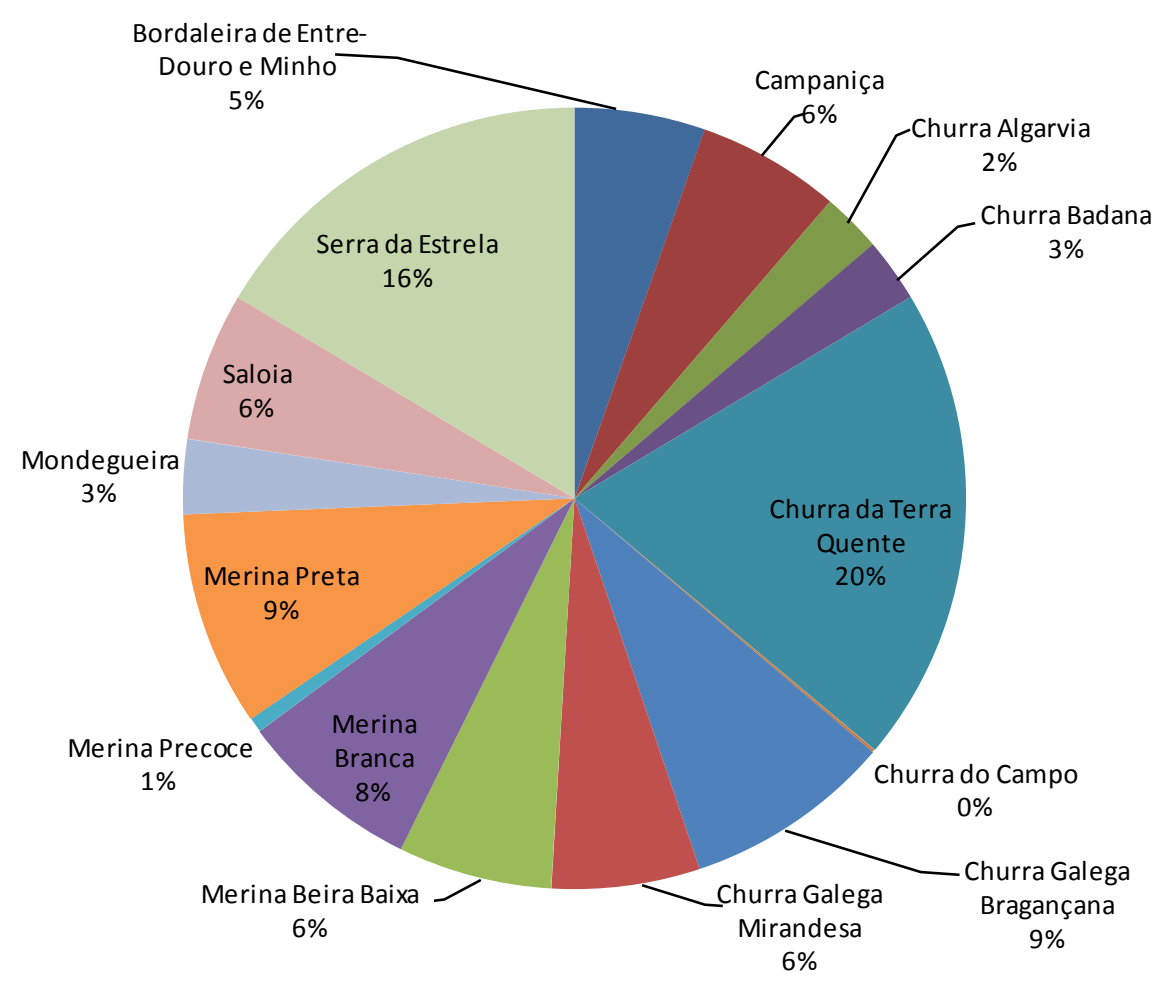

Figure 21. Local breed sheep.

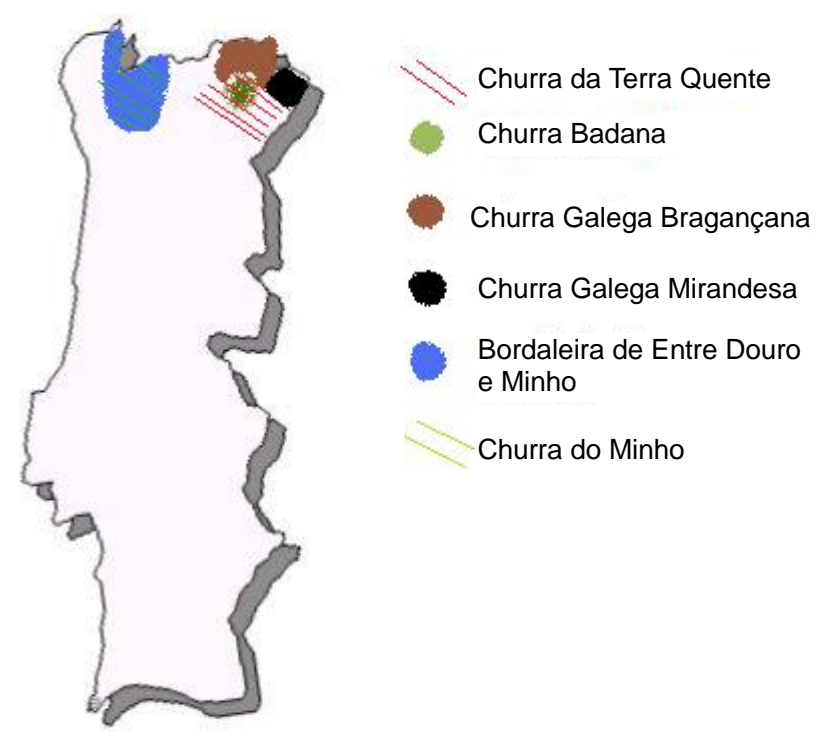

Figure 22. Local sheep breeds from the North. 
country, for it is produced is a vast area extending from center-north to center-south, with the main purpose of producing milk. There are also three breeds with meat production aptitude: Churra do Campo, Mondegueira and Saloia.

Figure 23 illustrates the distribution of native breeds of sheep in the central region of the country.

The south of Portugal is the region with least sheep breeds: Campaniça and Churra Algarvia. They are both meat production oriented breeds, Campaniça being the main breed, and Churra Algarvia facing extinction for economic reasons.

Figure 24 illustrates the distribution of native breeds of sheep in the southern region.

The five local goat breeds are distributed over the north of the country (Serrana and bravia breeds) and the south (Algarvia, Serpentine and Charnequeira). The most representative breed, with a population around 20,000 females, is Serrana, representing nearly $50 \%$ of the national herd of indigenous goats (Table 4, Figure 28).

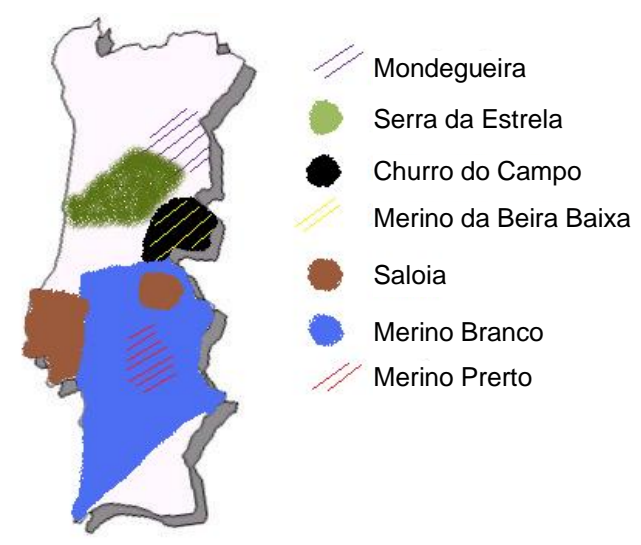

Figure 23. Sheep local breeds from the center.

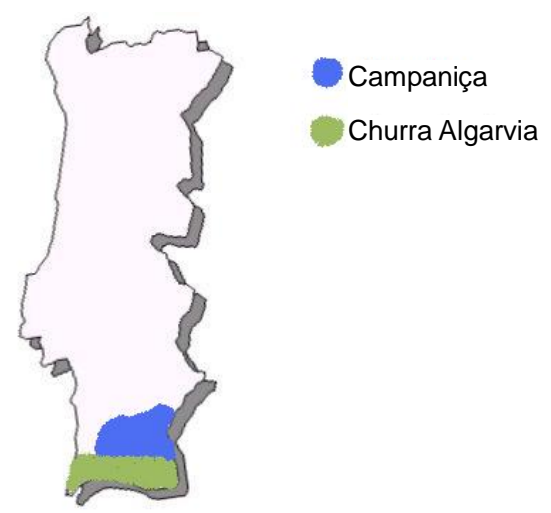

Figure 24. Local sheep breeds from the south.

Table 4. Local goat breeds.

\begin{tabular}{cc}
\hline Breed & Females $\left(\mathrm{N}^{\circ}\right)$ \\
\hline Algarvia & 4.133 \\
Serrana & 19.338 \\
Serpentina & 3.873 \\
Bravia & 9.700 \\
Charnequeira & 4.734 \\
Total & 41.778 \\
\hline
\end{tabular}


The 40,000 indigenous females represent $10 \%$ of the goat population and $28 \%$ of goat milk production. Serrana breed is referred to as the most representative (46\%, Figure 25) and Serpentina, Algarvia and Charnequeira are on the brink of extinction, with fewer than 4000 females each.

\subsection{Production Systems and Rank Organization}

As showed in Table 5, there are different systems for sheep production in each region. In the Douro region, in northern Portugal, owners depend on the amount of private land they possess, since they use it for grazing purposes, especially the marshes. This grazing system has a great ecological value because the areas are rich in diversified flora and are included in protected areas.

As one goes eastwards into the complex systems of Terra Fria and Beira Alta, one realizes there is a mixture of systems. In some areas, the production is mostly done on an intensive basis, as is the case of "Queijo Terrincho-DOP”" Although there has been some decrease in this productive structure, in this area owners take all the sheep to graze in a certain area in turns, using a system called "vezeira"2.

In Serra da Estrela, due to the evolution of the milk market, there have been changes in local habits and traditions. Years ago the system used was "Transhumance". The herders would tend the herds taking them to a place where they would stay for the whole of the winter, before coming back to the mountain ranges of Serra da

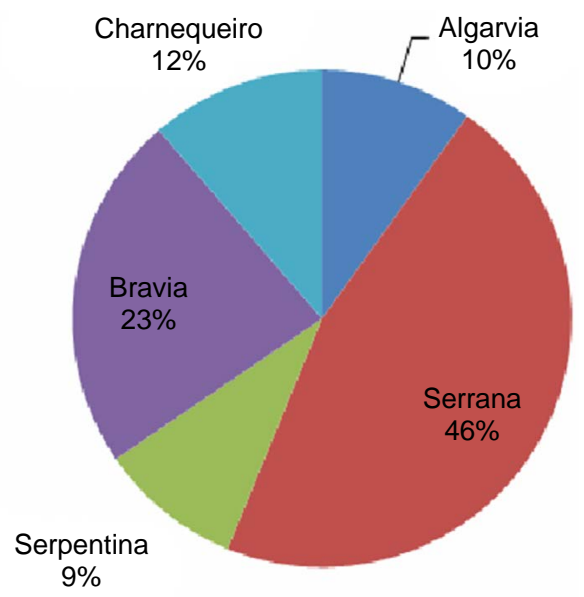

Figure 25. Goat local breeds.

Table 5. Different production systems, its characterization and risk factors.

\begin{tabular}{|c|c|c|c|}
\hline Production System & Autochthonous breeds & Characterization & Risk Factors \\
\hline $\begin{array}{l}\text { Galaico-Duriense grazing } \\
\text { system }\end{array}$ & $\begin{array}{l}\text { Churra do Minho and } \\
\text { Churra Galega Mirandesa }\end{array}$ & $\begin{array}{l}\text { Small familiar exploration. } \\
\text { Private pasture areas (marshes). }\end{array}$ & $\begin{array}{l}\text { Decrease of pastoral activity. } \\
\text { Human desertification. }\end{array}$ \\
\hline $\begin{array}{l}\text { Complex systems from Terra } \\
\text { Fria and Beira Alta }\end{array}$ & $\begin{array}{l}\text { Churra Galega } \\
\text { Bragançana }\end{array}$ & $\begin{array}{l}\text { Small familiar exploration. } \\
\text { Community grazing system. }\end{array}$ & $\begin{array}{l}\text { Decrease of pastoral activity. } \\
\text { Human desertification. }\end{array}$ \\
\hline $\begin{array}{l}\text { Serra da Estrela } \\
\text { grazing system }\end{array}$ & Serra da Estrela & $\begin{array}{l}\text { Small familiar exploration. } \\
\text { Dynamic milk market - adaptation } \\
\text { of traditional cheese production. }\end{array}$ & $\begin{array}{l}\text { Decrease of pastoral activity. } \\
\text { Human desertification. }\end{array}$ \\
\hline $\begin{array}{l}\text { Grazing system used in the } \\
\text { Center (Maciço Calcário } \\
\text { Estremenho) }\end{array}$ & Mondegueira & $\begin{array}{l}\text { Small familiar exploration. } \\
\text { Utilization of natural pastures. }\end{array}$ & $\begin{array}{l}\text { Decrease of pastoral activity. } \\
\text { Human desertification. }\end{array}$ \\
\hline $\begin{array}{l}\text { Mixed system used } \\
\text { in Alentejo }\end{array}$ & Merina and Campaniça & $\begin{array}{l}\text { System based on arable lands } \\
\text { and private natural pastures. }\end{array}$ & $\begin{array}{l}\text { Competition with other activities. } \\
\text { System balance depends on } \\
\text { agricultural policy. }\end{array}$ \\
\hline $\begin{array}{l}\text { Serra Algarvia } \\
\text { grazing system }\end{array}$ & Churra Algarvia & $\begin{array}{l}\text { Small familiar exploration } \\
\text { with private pasture areas. }\end{array}$ & $\begin{array}{l}\text { Decrease of pastoral activity. } \\
\text { Human desertification. }\end{array}$ \\
\hline
\end{tabular}

Source: Fernandes et al. [4].

${ }^{1}$ Portuguese acronym of Protected Denomination of Origin-PDO.

${ }^{2}$ The Portuguese word vezeira is a derivative from vez which means turn. 
Estrela in summer. The place of choice was usually in Alentejo, which meant herds would have to travel for many miles. As the production intensified, this became not so convenient; therefore, herders only go down to the valley in winter and get back to the mountain range in summer. There has also been a growing specialization in milk and cheese production, as the "Queijo Serra da Estrela-DOP" is the most appreciated cheese in the country. This system is not declining, unlike the extensive grazing due to the lack of herders.

The grazing system used in the Center is declining due to the reduced productivity and lack of labor. Clearings providing enriched pastures are now being occupied by shredders and some flora species have already disappeared.

In Alentejo, the system is characterized by large areas of land where sheep, cows and pigs are extensively produced. Sheep production has been increasing in the last years, assuming an important ecological value in open fields.

The Serra Algarvia grazing system occupies low productivity areas that demand a great effort. Maintaining this system is obviously important to contradict the human desertification.

Although sheep production is mainly oriented for meat production, there is still a significant amount of milk and cheese being produced, the latter being progressively intensified unlike the former, which is being done on an extensive basis [4].

\section{Meat Production and Its Market in Portugal}

\subsection{Sheep and Goat Meat and Milk Production}

Domestic production of sheep and goats has evolved quite negatively and amounts to 17.5 tons and 2000 tons (Figure 26).

Sheep and goat milk production now stands below 80,000 tons and 38,000 tons, respectively, and has also evolved negatively. However, in recent years, there has been a slight recovery of goat milk at the production level (Figure 27). The production of sheep and goat cheese hover around 12,000 and 2000 tons, respectively, and its evolution follows the same pattern as milk production.

\subsection{Producer Prices}

Prices in sheep production tend to be stable with small increases and decreases, at least for the producer. Over

ton.

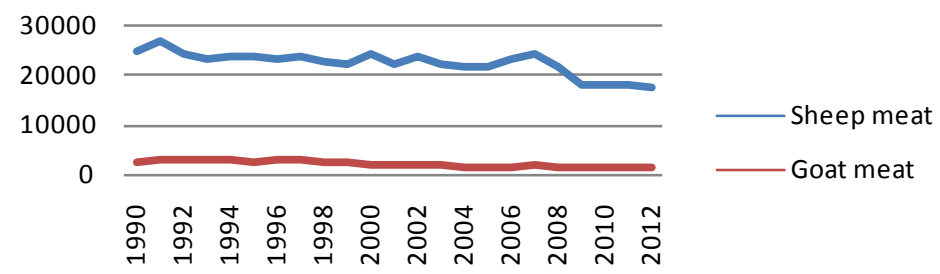

Figure 26. Sheep and goat meat production. Source: Agricultural Statistics 2012, INE.

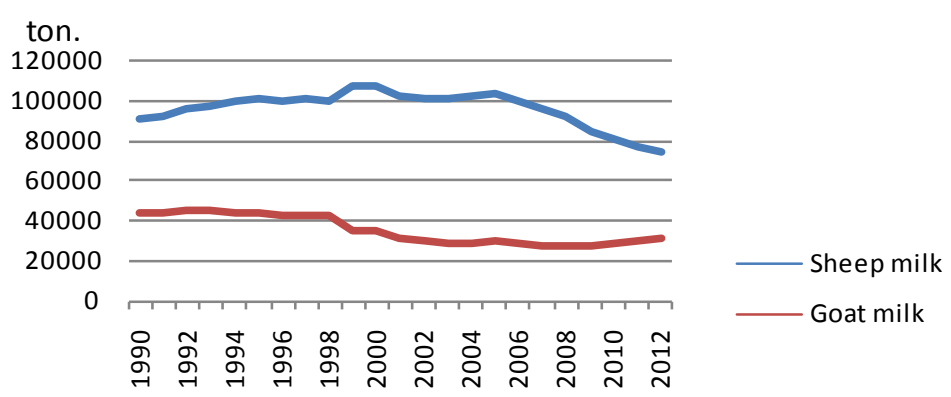

Figure 27. Sheep and goat milk production. Source: Agricultural Statistics 2012, INE. 
recent years, producer prices have been rather stable, despite the current tendency to increase slightly. Transformation and distribution always demand higher prices than the producer. The difference between prices on the part of the producer and on the part of transformation and distribution is clear (Figure 28), although there has been a decrease of the latter and an increase of the former in recent years. This difference is the main reason why local and regional markets have been growing as a result of the economic crisis the country is in.

Prices established by producers tend to vary according to market prices, although the former depend mostly on the latter. Lambs are sold either before they reach the weight of $28 \mathrm{~kg}$ or after. Since the younger ones are the most appreciated, their value rises to almost $1 €$ higher than the price of older lambs. Because they are reproducers and they are vital for production, ewes have the higher value (Table 6). The economic instability and market fluctuations have an impact on the prices established by producers as can be seen on Table 6 . The biggest decrease happened between 2011 and 2012 in lambs weighing more than $28 \mathrm{~kg}$; the difference narrows down when one speaks younger lambs [5].

\subsection{Consumption per Capita, Self-Sufficiency and Trade Balance}

At the beginning of the nineties, sheep and goat meat per-capita reached $4 \mathrm{~kg}$ but has negatively evolved since then, presently standing at $2.5 \mathrm{~kg}$ per capita, which is lower than the rate in the mid-eighties (Figure 29).

In the early eighties, Portugal was self-sufficient as regards sheep and goat production. Currently, the level of supply is already lower than $80 \%$ (Figure 30). The negative joint consumption per capita and the level of supply of sheep and goat meat reinforces the strong decline of the activity and of the national production of sheep and goats.

Analyzing the information below, one verifies that Portugal is self-sufficient in terms of sheep and goat meat (around 70\%), as exports are very low when compared to the imports which hover around 6,500 tons of sheep meat. Table 7 allows us to compare import and export prices, which leads to the conclusion that, while live sheep are sold at higher prices, sheep meat is bought at a lower price meaning there is some recovery.

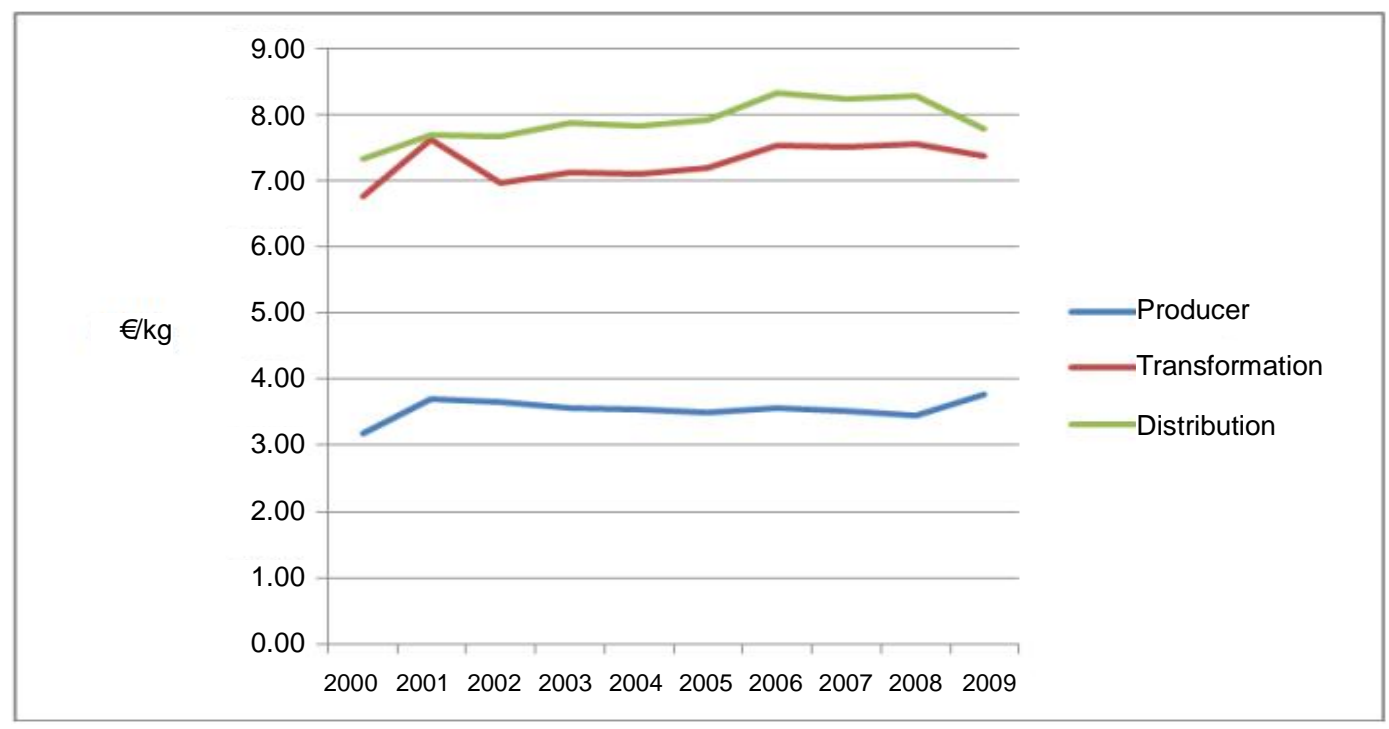

Figure 28. Evolution of sheep meat prices. Source: CAP.

Table 6. Evolution of producer prices.

\begin{tabular}{cccc}
\hline & 2010 & 2011 & 2012 \\
\hline Lambs $(<28 \mathrm{~kg})$ & $2.72 €$ & $2.81 €$ & $2.79 €$ \\
Lambs $(>28 \mathrm{~kg})$ & $1.94 €$ & $1.96 €$ & $1.82 €$ \\
Ewes & $13.02 €$ & $12.97 €$ & $12.97 €$ \\
\hline
\end{tabular}

Source: Agricultural Statistics 2012, INE. 
$\mathrm{kg} / \mathrm{hab}$.

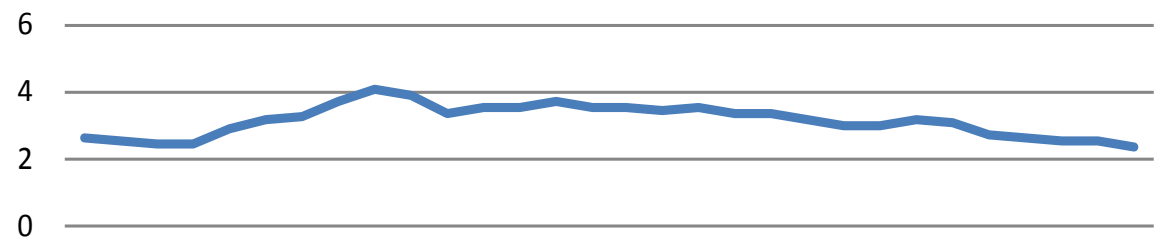

198419861988199019921994199619982000200220042006200820102012

Figure 29. Evolution of consumption per capita. Source: Agricultural statistics 2012, INE.

$\%$

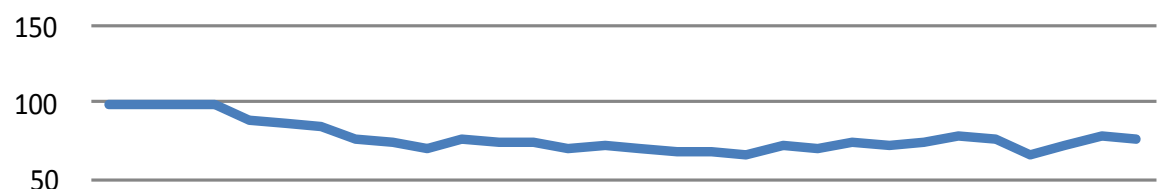

0

198419861988199019921994199619982000200220042006200820102012

Figure 30. Self-sufficiency. Source: Agricultural statistics 2012, INE.

Table 7. Imports and exports.

\begin{tabular}{ccccccc}
\hline 2012 & \multicolumn{3}{c}{ Imports } & \multicolumn{3}{c}{ Exports } \\
& Tons & $1000 €$ & $€ / \mathrm{kg}$ & Tons & $1000 €$ & $€ / \mathrm{kg}$ \\
Live sheep & 1315 & 5046 & 3.83 & 1494 & 5352 & 3.58 \\
Sheep meat & 6508 & 31411 & 4.83 & 421 & 2085 & 4.95 \\
\hline
\end{tabular}

Source: Agricultural Statistics 2012, INE.

We can conclude that Portugal has been self-sufficient in terms of sheep meat, which means it only depends on foreign supply in about $30 \%$. The ups and downs can be a direct effect of the instability of the economic system and the depression that the country has been living in recent years [5].

\subsection{Main Source and Destination Markets}

Sheep production has a well-established world trade market in which the main exported and imported products are the live animals and their meat (fresh, chilled or frozen). The main live sheep exporters in the world are France (626,904 tons in 2012) and Australia (108,417 tons). Portugal occupies the 27th place, having exported about 1493 tons in 2012, about 625,000 tons less compared to France. France is also the biggest importer of live sheep in the world, having imported 367,032 tons in 2012, followed by Portugal, (1244 tons) occupying the 31st place. New Zealand takes the lead in sheep meat exports, with 436,336 tons (in 2012); Portugal comes in second in this statistic. Australia is also a significant exporter of sheep meat reaching 355,854 tons. Portugal occupies the 28th place in sheep meat imports, with about 6551 tons, very far from the leader, China, with 123,939 tons.

Portugal imports live sheep mostly, from three different sources: Spain, France and Greece supply us with 1152 tons, 64 and 28 tons respectively. Spain and France are also the main destination markets for Portuguese live sheep, importing about 1237 and 256 tons, respectively. In terms of sheep meat, Angola takes a leading place in imports from Portugal, with 143 tons, followed by France and Libya. Spain and Italy have minor roles in this statistic. Portugal gets its supply of sheep meat from Spain and New Zealand, 2589 and 1709 tons, respectively. France, United Kingdom, Argentina and Ireland are also relevant contributors for our imports [6]. 


\section{Quality and Differentiation}

\subsection{Qualified Products in Sheep and Goat Production}

Even when products look the same, we cannot qualify them as being exactly the same. To guaranty some differentiation between high quality and current products, there are specific denominations and standards. Products bearing the Protected Denomination of Origin (PDO) label are those whose production, transformation and elaboration occur within a well delimited, geographical area. Of all the denominations, PDO follows the strictest rules. There is also the Protected Geographical Indication (PGI), indicating that only a stage of the whole process (production, transformation or elaboration) needs to be done in a well delimited geographical area.

There is still a third differentiation, the Traditional Specialty Guaranteed (TSG). Products bearing this label do not have to be manufactured in a specific zone at any stage of the process but must be produced according to a traditional method.

All these European designations intend to distinguish traditional products that are high in quality and relevant for the country.

The most important DOP product within sheep production in Portugal is the cheese, as there are many different varieties. The most famous DOP cheese is "Queijo da Serra da Estrela", as well as the cottage cheese with the same name; but there are others as famous in other areas of the country like "Queijo Terrincho", "Queijo de Azeitão" and "Queijo de Nisa".

Although these are the most known ones, Portugal produces six more DOP cheeses: "Queijo Amarelo da Beira Baixa”, “Queijo de Castelo Branco", "Queijo Picante da Beira Baixa”(and its respective cottage cheese), "Queijo de Évora”, "Queijo Rabaçal” and "Queijo Serpa”. Some meat products have also been labeled with the DOP seal, namely "Cordeiro Bragançano", "Borrego Terrincho" and "Borrego Serra da Estrela”, all lambs. These products are usually named after the geographical area where the animals were bred or the breed that produces the primary product.

PGI products in sheep production are fewer than PDO ones, but there are some, nevertheless, mainly lamb meat. Alentejo, in the south of Portugal, has two PGI products: "Borrego do Nordeste Alentejano" and "Borrego do Baixo Alentejo". Other regions have PGI certified meat lamb like Barroso ("Cordeiro Barroso"), Montemor-o-Novo ("Borrego de Montemor-o-Novo") and Beiras ("Borrego da Beira"). Although most sheep PGI products are meat oriented, there is also one cheese beraing this denomination, the "Queijo Mestiço de Tolosa". Some of these cheeses are made of a mixture of sheep and goat milk; nonetheless most PDO and PGI products made in Portugal come from sheep production. There's still no TSG licensed product in sheep production.

Trás-os-Montes Goat Cheese, obtained from goat milk, is the only goat cheese produced from goats of the Serrana breeding with a designation of origin or geographical indication in Portugal. In general, the production of PDO/PGI products reported is low.

\subsection{PD0/PGI Sheep Meat Production}

Although there is a well-established production of sheep as shown by the numbers presented earlier in this revision, PDO and PGI products hold only small segment of the market, therefore not contributing much to this statistics. Earlier in this work we established the production of sheep as having been around 8 tons of sheep meat in 2012. Table 8 shows the amount of certified PDO or PGI sheep meat produced in the country in 2008 and 2009. There are only records of "Borrego do Nordeste Alentejano IGP" and "Borrego Terrincho DOP" having been produced in these two periods, which does not necessarily mean that the other products were not produced at all. Despite not being a PDO product, "Borrego do Nordeste Alentejano IGP" has the greatest production in the country, reinforcing the notion that Alentejo is the main sheep production area. Although the production is not small, it is not very significant either when compared to the total of 8 tons. That is so because, although the animals have the same breed, products are not certified due to lack of some specification.

The production of meat of "Borrego Terrincho DOP" has increased whereas the production of "Borrego do Nordeste Alentejano IGP" has decreased. In spite of it, the production of "Borrego do Nordeste Alentejano IGP” has increased.

The goat meat sector in Portugal includes other six PDO/PGI products but their levels of production are too insignificant or null. The PDO/PGI products (meat and cheese) originated in the sheep and goat sectors are associated to indigenous breeds from specific regions of the country whose flocks have been reduced. Thus, their 
little impact and presence in the market is not only the result of their small dimension, but also of the lack of dynamism of the entities responsible for managing them (Table 9).

\subsection{PD0/PGI Sheep Meat Commercialization System}

Almost all of these high quality products can now be found in every shopping mall. Most of them started out in small family businesses that evolved and became rather successful. Some PDO/PGI products have a seasonal demand, especially around the holidays, which affects the commercialization system. Therefore, producers are focused on meeting the holiday demand so that they can make up for the rest of the year (Table 10).

Table 8. PDO and PGI production in portugal.

\begin{tabular}{|c|c|c|c|c|c|c|c|c|}
\hline \multirow{2}{*}{ Product } & \multicolumn{2}{|c|}{$\leq 7 \mathrm{~kg}$} & \multicolumn{2}{|c|}{$7-13 \mathrm{~kg}$} & \multicolumn{2}{|c|}{$>13 \mathrm{~kg}$} & \multicolumn{2}{|c|}{ Total $(\mathrm{kg})$} \\
\hline & 2008 & 2009 & 2008 & 2009 & 2008 & 2009 & 2008 & 2009 \\
\hline Borrego da Beira IGP & 0 & 0 & 0 & 0 & 0 & 0 & 0 & 0 \\
\hline Borrego de Montemor-o-Novo IGP & 0 & 0 & 0 & 0 & 0 & 0 & 0 & 0 \\
\hline Borrego do Baixo Alentejo IGP & 0 & 0 & 0 & 0 & 0 & 0 & 0 & 0 \\
\hline Borrego do Nordeste Alentejano IGP & 0 & 0 & 74,184 & 57,720 & 0 & 0 & 74,184 & 5745 \\
\hline Borrego Serra da Estrela DOP & 0 & 0 & 0 & 0 & 0 & 0 & 0 & 0 \\
\hline Borrego Terrincho DOP & 154 & 225 & 0 & 0 & 0 & 0 & 154 & 225 \\
\hline Cordeiro Bragançano DOP & 0 & 0 & 0 & 0 & 0 & 0 & 0 & 0 \\
\hline Cordeiro de Barroso IGP & 0 & 0 & 0 & 0 & 0 & 0 & 0 & 0 \\
\hline Total (kg) & 154 & 225 & 74,184 & 57,720 & 0 & 0 & 74,184 & 5745 \\
\hline
\end{tabular}

Source: Inquiry to the Managing Groups of DOP/IGP/EGT Products 2008 and 2009, GPP.

Table 9. Farms producing PDO and PGI products.

\begin{tabular}{ccc}
\hline Product & 2008 & 2009 \\
Borrego da Beira IGP & 0 & 0 \\
Borrego de Montemor-o-Novo IGP & 0 & 0 \\
Borrego do Baixo Alentejo IGP & 0 & 0 \\
Borrego do Nordeste Alentejano IGP & 29 & 54 \\
Borrego Serra da Estrela DOP & 0 & 3 \\
Borrego Terrincho DOP & 3 & 0 \\
Cordeiro Bragançano DOP & 0 & 0 \\
Cordeiro de Barroso IGP & 32 & 52 \\
Total of Productions & 32 \\
\hline
\end{tabular}

Source: Inquiry to the Managing Groups of PDO/PGI/STG Products 2008 and 2009, GPP.

Table 10. Percentage of PDO and PGI products sales by entity.

\begin{tabular}{ccccc}
\hline Sector & Year & Producer Groups (\%) & Producers (directly) (\%) & Other entity (\%) \\
\hline \multirow{2}{*}{ Sheep meat } & 2008 & 100.00 & 0.00 & 0.00 \\
& 2009 & 66.67 & 0.00 & 33.33 \\
\hline
\end{tabular}

Source: Inquiry to the Managing Group, GPP, 2012. 
Based on the statistics presented in the previous and next table it is possible to conclude that $100 \%$ of the products were sold by producer groups, but are now being sold also by other entities. Nevertheless, local or regional markets are growing in comparison with the national market. Since for Portugal the international markets are still new territory, there is a chance to see it as an opportunity and try and launch these products abroad (Table 11).

\subsection{Alternative Sheep Production}

Although most of the sheep production is done on an extensive basis, there are alternatives to this method. Biologic agriculture is an increasing method in which the producer does not use fertilizers or chemicals of any sort to produce the animal feed. This production obeys some strict rules like for instance the land having to be set aside for two or three years before sowing (Table 12).

Of all the animal biological productions, sheep biological production is the second biggest in the country. Alentejo is the main region producing sheep biologically, but the Center is also somewhat relevant. Although there is a significant difference between the numbers of animals in the Center region and in Alentejo, in terms of production the difference is minimal, which means that there are more animals per production [5].

This type of production is still developing and has an amazing potential for future sheep production.

\subsection{Global Analysis}

Like many other sectors, sheep production depends on several factors, both internal and external. Taking into account all the variables that were discussed along this revision, we can now proceed to a global analysis of this sector. Based on the Swot Analysis or Swot Matrix, there is a need to identify the Strengths and Weaknesses of the sector and match them with the Opportunities and Threats of the external environment.

Strengths are the characteristics of the sector that give it an advantage over others, while weaknesses are the opposite, that is, the characteristics that become a disadvantage. Opportunities and threats are set by the external conditions, the former being the elements that can be exploited to the advantage of the project and the latter the elements in the environment that could cause some problems in the sector. Table 13 presents an overview of the strengths, weaknesses, opportunities and threats of the sheep production sector.

\section{Conclusion}

In conclusion, sheep production is a rising production with many challenges ahead. Although the production has

Table 11. National and international commercialization system.

\begin{tabular}{cccccc}
\hline Sector & Year & $\begin{array}{c}\text { Local or Regional } \\
\text { Market (\%) }\end{array}$ & $\begin{array}{c}\text { National Market } \\
\text { (\%) }\end{array}$ & $\begin{array}{c}\text { International Market } \\
- \text { EU (\%) }\end{array}$ & $\begin{array}{c}\text { International Market } \\
\text { - outside EU (\%) }\end{array}$ \\
\hline \multirow{2}{*}{ Sheep meat } & 2008 & 5.0 & 95.0 & 0.0 & 0.0 \\
& 2009 & 33.3 & 66.7 & 0.0 & 0.0 \\
\hline
\end{tabular}

Source: Inquiry to the Managing Groups, GPP, 2012.

Table 12. Statistics about biological sheep production.

\begin{tabular}{|c|c|c|c|c|}
\hline Regions & Farmers $\left(n^{\circ}\right)$ & (\%) & Animals $\left(\mathrm{n}^{\circ}\right)$ & (\%) \\
\hline Portugal & 194 & 100 & 64,412 & 100 \\
\hline North & 29 & 15 & 3683 & 5 \\
\hline Centre & 79 & 41 & 22,794 & 36 \\
\hline Alentejo & 83 & 43 & 36,273 & 56 \\
\hline Algarve & 2 & 1 & 1659 & 3 \\
\hline Azores & 1 & 1 & 3 & 0 \\
\hline Madeira & 0 & 0 & 0 & 0 \\
\hline
\end{tabular}

Source: Agricultural Statistics 2012, INE. 
Table 13. SWOT Analysis of the sheep and goat production sector.

\begin{tabular}{|c|c|c|c|}
\hline Strengths & Weaknesses & Opportunities & Threats \\
\hline 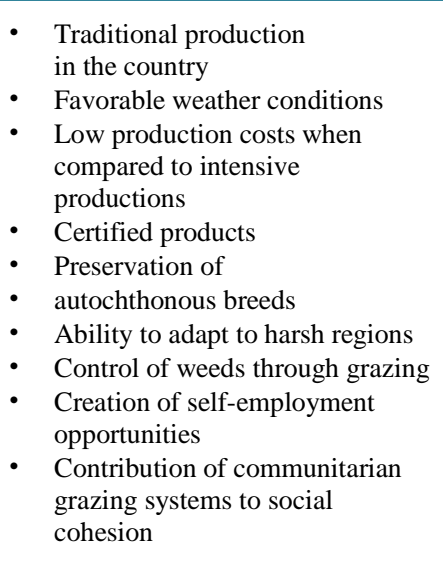 & $\begin{array}{ll}\text { - } & \text { Seasonal products } \\
\text { - } & \text { Weak distribution } \\
\text { channels } \\
\text { - }\end{array}$ & $\begin{array}{ll}\text { - } & \text { Increased search for } \\
\text { traditional products } \\
\text { - } & \text { Development of new } \\
\text { production technologies } \\
\text { - } & \text { Possibilities of increasing } \\
\text { - } & \text { productivity and efficiency } \\
\text { aintenance of abandoned } \\
\text { - } \quad \text { Low initial investment } \\
\text { - } & \text { Existence of many } \\
& \text { producers associations to } \\
& \text { maintain breeds and } \\
& \text { support other producers } \\
\text { - } & \text { Reducing fire risk } \\
\text { - } & \text { Reducing human } \\
\text { - } & \text { desertification } \\
\text { High unemployment rate }\end{array}$ & $\begin{array}{ll}\text { - } & \text { Other meat production } \\
\text { chains with higher growth } \\
\text { - } & \text { Lack of competitiveness } \\
\text { - } & \text { Higher prices than other } \\
\text { species } \\
\text { - } & \text { Forestation } \\
\text { - } & \text { Difficult access to grazing } \\
\text { areas } \\
\text { - }\end{array}$ \\
\hline
\end{tabular}

risen in recent years, there is still room for improvement and development. The meat production sector still has to grow in terms of certified products, if it is to reach external markets. It is necessary for producers to invest in this approach so the productions can increase not just in number but also in dimension. It is necessary to give a better assistance to producers and try to increase their levels of schooling, so there will be more innovation and more productivity. Alternative sheep productions and certification of products can be a good way to boost the market, because there is a higher demand of products that resemble the ones that are traditional and homemade. There is also a great need to support producers, increasing the prices practiced by them or reducing the difference between the prices practiced by transformation and distribution. This and the increase of local and regional markets, where producers can sell their products directly without having to go through the transformation or distribution channels can be appealing for new consumers.

\section{References}

[1] Instituto Nacional de Estatística (2011) Recenseamento Agrícola 2009—Análise dos principais resultados. INE, Lisboa.

[2] Instituto Nacional de Estatística (2001) Recenseamento Geral da Agricultura 1999—Análise de resultados. INE, Lisboa.

[3] Estratégia para a Conservação e Melhoramento das Raças Autóctons (2007-2013) Direção Geral de Veterinária.

[4] Fernandes, J.P., et al. (2002) Cartografia dos Sistemas Extensivos de Pastoreio em Portugal Continental.

[5] Instituto Nacional de Estatística (2013) Estatísticas Agrícolas 2012. INE, Lisboa.

[6] Market Analysis and Research, International Trade Centre (2008) Trade Map. http://www.trademap.org/ 
Scientific Research Publishing (SCIRP) is one of the largest Open Access journal publishers. It is currently publishing more than 200 open access, online, peer-reviewed journals covering a wide range of academic disciplines. SCIRP serves the worldwide academic communities and contributes to the progress and application of science with its publication.

Other selected journals from SCIRP are listed as below. Submit your manuscript to us via either submit@scirp.org or Online Submission Portal.
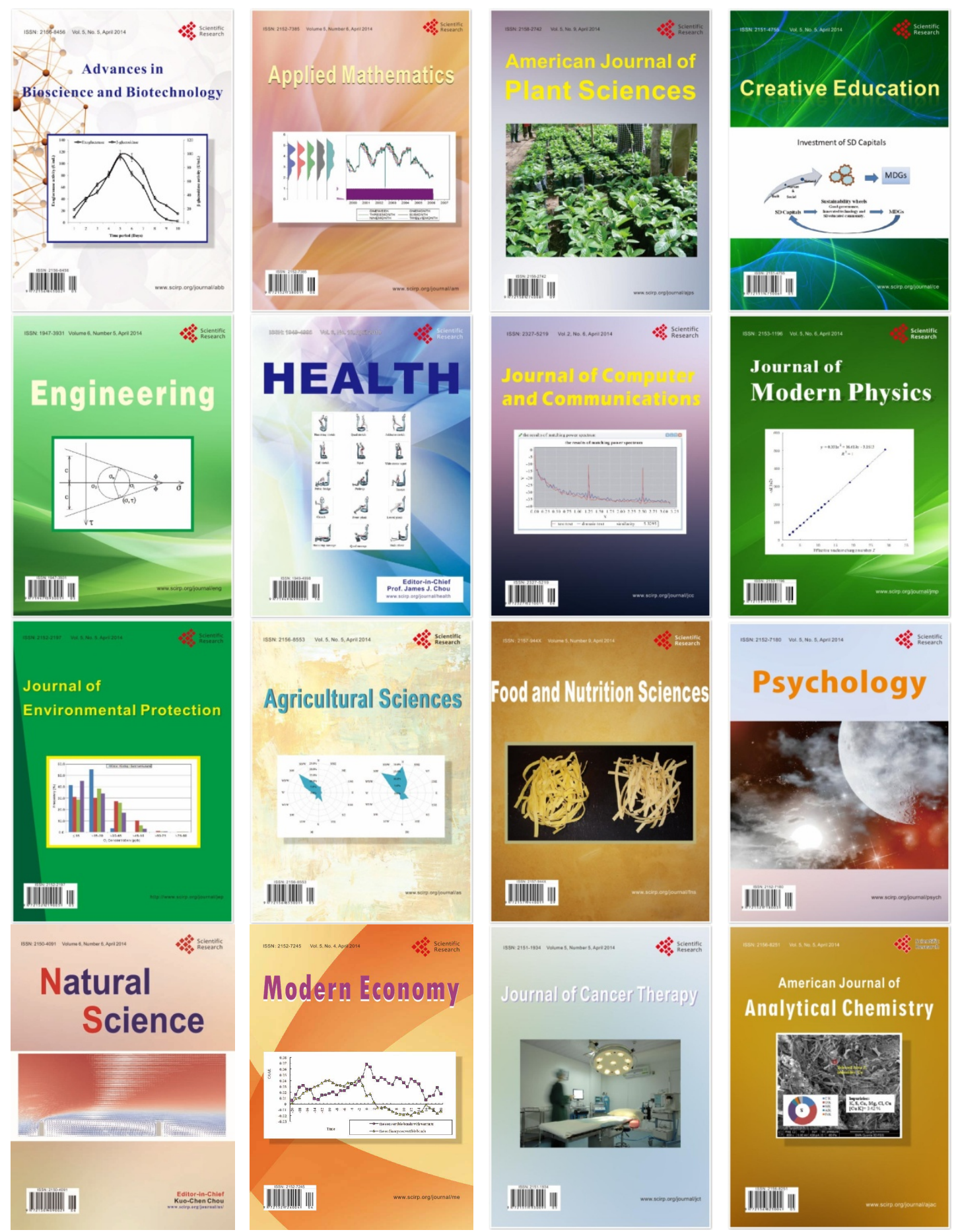